\title{
Dynamics of nitrogen and active nitrogen components across seasons under varying stand densities in a Larix principis- rupprechtii (Pinaceae) plantation
}

\author{
Junyong Ma ${ }^{1}$, Hairong Han ${ }^{\text {Corresp., }}{ }^{1}$, Wenwen Zhang ${ }^{1}$, Xiaoqin Cheng ${ }^{1}$ \\ ${ }^{1}$ Beijing Forestry University, Key laboratory of ministry of Forest Cultivation and Conservation of Ministry of Education, Beijing, China \\ Corresponding Author: Hairong Han \\ Email address: hanhr6015@bjfu.edu.cn
}

Changes in the concentration of soil $\mathrm{N}$ or its components may directly affect ecosystem functioning in forestry. Thinning of forest stands, a widely used forestry management practice, may transform soil nutrients directly by altering the soil environment, or indirectly by changing above- or belowground plant biomass. The study objectives were to determine how tree stem density affects the soil $\mathrm{N}$ pool and what mechanisms drive any potential changes. In this study, $\mathrm{N}$ and its active components were measured in the soil of a Larix principis-rupprechtiiplantation across two full growing seasons, in twelve $25 * 25 \mathrm{~m}$ plots: LT (low thinning, removal of $15 \%$ of the trees, three plot repetitions), MT (35\% removal) and $\mathrm{HT}$ (50\% removal) and CK (no thinning control). Environmental indices, like the light condition, soil reoperation, soil temperatures and prescription, were measured in the plots also. Results indicated that STN (soil total nitrogen) was affected by tree stem density adjustments in the short-term; STN generally increased with decreasing tree stem density, reaching its highest concentration in the MT treatment before decreasing in HT. This pattern was echoed by the DON/STN ratio (DON, dissolve organic nitrogen) under MT. A lower DON/STN was measured across the seasons. MBN (microbial biomass nitrogen) and the SOC/STN (SOC, soil organic carbon) ratio and density treatments influenced MBN concentration and inhibited SOC/STN. MT tended to accumulate more STN, produce lower DON/STN and had a generally higher microbial activity, which may be partly ascribed to the higher MBN value, MBN/STN ratio and lower DON/STN. The water conditions (soil moisture), light and soil temperatures may partly be responsible for the $\mathrm{N}$ pool dynamic in the different density treatments. 
1 Dynamics of nitrogen and active nitrogen components across seasons under varying stand

\section{2 densities in a Larix principis-rupprechtii (Pinaceae) plantation}

3 Author information: Junyong Ma (Email: mjy172404707@me.com); Hairong Han* (Email:

4 hanhr6015@bjfu.edu.cn). Wenwen Zhang (Email: 360486711@qq.com); Fengfeng Kang (Email:

5 phoonkong@bjfu.edu.cn); Xiaoqin Cheng (Email: cxq_200074@163.com); All the authors from “Key

6 laboratory of ministry of Forest Cultivation and Conservation of Ministry of Education, Beijing Forestry

7 University, Beijing 100083, China". (*Corresponding author: Hairong Han)

8 


\section{Abstract}

12 Changes in the concentration of soil $\mathrm{N}$ or its components may directly affect ecosystem functioning in forestry.

13 Thinning of forest stands, a widely used forestry management practice, may transform soil nutrients directly by

14 altering the soil environment, or indirectly by changing above- or belowground plant biomass. The study objectives were to determine how tree stem density affects the soil $\mathrm{N}$ pool and what mechanisms drive any potential changes. In this study, $\mathrm{N}$ and its active components were measured in the soil of a Larix principisrupprechtii plantation across two full growing seasons, in twelve $25 * 25 \mathrm{~m}$ plots: LT (low thinning, removal of $15 \%$ of the trees, three plot repetitions), MT (35\% removal) and HT (50\% removal) and CK (no thinning control).

Environmental indices, like the light condition, soil reoperation, soil temperatures and prescription, were adjustments in the short-term; STN generally increased with decreasing tree stem density, reaching its highest concentration in the MT treatment before decreasing in HT. This pattern was echoed by the DON/STN ratio (DON, dissolve organic nitrogen) under MT. A lower DON/STN was measured across the seasons. MBN (microbial biomass nitrogen) and the SOC/STN (SOC, soil organic carbon) ratio and density treatments influenced MBN concentration and inhibited SOC/STN. MT tended to accumulate more STN, produce lower DON/STN and had a generally higher microbial activity, which may be partly ascribed to the higher MBN value, MBN/STN ratio and lower DON/STN. The water conditions (soil moisture), light and soil temperatures may partly be responsible for the $\mathrm{N}$ pool dynamic in the different density treatments. 


\section{Introduction}

Forest ecosystems have often been proposed to play a part in the effective mitigation of climate change

(Canadell and Raupach 2008; Miles and Kapos 2008). Playing a major role in global nutrient cycles and providing regulating and supporting services, soils are one of the most important components of forest ecosystems (Bravo-Oviedo et al. 2015). Previous studies have suggested that increasing levels of nitrogen (N) deposition could impact the sustainability of carbon (C) sinks in forest ecosystems (Townsend et al. 1996) because of interactions between the carbon and nitrogen cycles (Rastetter et al. 1997). However, due to the complexity of the interactions between both cycles, how these cycles are coupled remains poorly understood (Mcguire et al. 2003). Studies (Aerts et al. 2012; Wieder et al. 2013) have shown that soil total nitrogen (STN), which has been widely studied in forest ecosystems (Hafner et al. 2005; Guan et al. 2015), and other land use conditions (Lehrsch et al. 2012; Zhao et al. 2017; Wang et al. 2017), respond to soil organic matter input. Therefore, aboveground changes may potentially alter $\mathrm{N}$ pools in temperate forests.

Thinning treatments are frequently utilized in forest management to promote undergrowth renewal, increase biodiversity and improve soil fertility (Pariona et al. 2003). Management of stem density has been shown to be important for maintaining forest ecosystem services and long-term productivity, and is thus a focus of much scientific study (Jackson et al. 2002; Crow et al. 2002). studies in terrestrial ecosystems have mainly focused on inorganic forms, such as ammonium $\left(\mathrm{NH}_{4}^{+}\right)$and nitrate 
49

50

51

52

53

54

can influence soil microbial activity and humus formation (Bravo-Oviedo et al. 2015). Dissolved organic nitrogen (DON) availability may dictate the structure and presence of bacterial communities (Ren et al. 2016), change rapidly in response to environmental factors and affect soil nutrient cycling (Iqbal et al. 2010). Although total soil microbial biomass nitrogen (MBN) tends to be low in absolute value, its turnover represents a significant contribution to the global nitrogen cycle (Jenkinson et al. 1988). The MBN reflects the activity of microorganisms (Wardle, 1992; Jiang et al. 2010). Global stocks of soil organic carbon (SOC) recently reached 2344 Pg (Stockman et al. 2013), a large percentage of the global soil carbon pool, concentrated in forest soils (Houghton, 1995; Dixon et al. 1994). Due the close relationship between C and N in forest soils (Tateno et al. 1997; Cleveland et al. 2007) the SOC/STN ratio acts as an index of the degree of correlation between C and N availability (Ge et al. 2013), as well as a sensitive indicator of soil quality (Gravel et al. 2010). This SOC/STN ratio can also detect plant growth (Zhang et al. 2011; Wieder et al. 2013).

Tree stem density adjustment via thinning is a common management practice in forest plantations; this widely used approach can affect the growth of the forest stand (Duan et al. 2010), aboveground plant biomass (Jessica et al. 2007) and understory biological diversity (Karlsson et al. 2002; Lähde et al. 2002). Thinning regulates the distribution of open growing space so that standing trees may benefit from reduced competition, increased growth and tree health (Smith et al. 1997; Jandl et al. 2007). Afforestation increases soil nitrogen accumulation and modifies nitrogen availability for micro-organismal growth (Deng et al. 2014), thereby potentially influencing elemental cycles in terrestrial ecosystems ( $\mathrm{Li}$ et al. 2012; Li et al. 2014). Studies (Aerts, et al. 2012; Wieder et al. 2013) have also shown that soil $\mathrm{N}$ responds to changes in soil organic matter inputs, which can then impact microbial processes. While many studies have focused on the soil carbon cycle in forest 
ecosystems ( $\mathrm{Lal}$ et al. 2004; Zou et al. 2005; Ares et al. 2010), rather less attention has been paid to the relationship between $\mathrm{C}$ and $\mathrm{N}$. Knowledge of how the active organic form of soil nitrogen varies with stand tree stem density and how SOC and STN are mechanistically linked is lacking.

In this study, within-growing-season variation in soil active nitrogen components was quantified for four different stand densities within a Larix principis-rupprechtii plantation located in a Northern Chinese montane secondary forest. Study hypotheses were first, that adjustments in the tree stem density would affect STN, and second, that soil N-components would play an important role in $\mathrm{N}$ cycling. The specific objectives were to determine: (1) how STN varies with stand tree stem density; (2) the contributions of each soil nitrogen component to variation in the nitrogen pool overall under different stand densities and in different seasons; and (3) how the environmental factors change according to thinning treatments and how those differences may influence the $\mathrm{N}$ pools.

\section{Materials and methods}

\subsection{Study area and experimental design}

The study was carried out in a plantation on Mt. Taiyue in Shanxi, North China (112 $00^{\prime} 47^{\prime \prime}$ E, 36 $46^{\circ} 05^{\prime \prime}$

$\mathrm{N} ; 112^{\circ} 01^{\prime} \sim 112^{\circ} 15^{\prime} \mathrm{E}, 36^{\circ} 31^{\prime} \sim 36^{\circ} 43^{\prime} \mathrm{N}$; elevation $2273-2359 \mathrm{~m}$ above sea level). This artificial forest is dominated by Larix principis-rupprechtii and has been protected since it was planted in the 1980s. The climate is the continental monsoon type with a humid, rainy summer and a cold, snowy winter. Mean annual air temperature is $8.7^{\circ} \mathrm{C}$, with an average minimum temperature of $-10.4^{\circ} \mathrm{C}$ in January and an average maximum of $17.4^{\circ} \mathrm{C}$ in July. The frost-free period lasts an average of 125 days, with the earliest frost generally in October and latest frost in April. Average annual rainfall ranges between 600 and $650 \mathrm{~mm} \cdot \mathrm{yr}^{-1}$, with precipitation 
occurring mainly from July to September. The soil type in the study plantation is Haplic luvisol, ranging from 50-110 cm thick, according to the World Reference Base (WRB) soil classification system (IUSS Working Group WRB, 2006).

Sampling was performed in stands selected to reflect average altitude $(2316 \mathrm{~m})$, grade $\left(24.3 \pm 0.83^{\circ}\right)$, slope direction (North) and soil conditions within the plantation. Measurements of these characteristics did not vary significantly among selected stands before the experimental treatments were applied (Table 1). After quantifying the initial characteristics of each quadrat, $1225 \mathrm{~m} \times 25 \mathrm{~m}$ quadrats, or "sample areas", were designated for four treatments (one CK contrast contained) in July 2010. Three control quadrats had initial stand densities averaging $2160 \pm 12$ stems ha-1 and no thinning treatment was applied (CK). Three quadrats each were selected to undergo the following treatments: $15 \%$ thinning (low thinning, LT) with tree stem density adjusted to $1834 \pm 12$ stems $\mathrm{ha}^{-1}$ (mean of three replications); 35\% thinning (moderate thinning, MT) with tree stem density adjusted to 1418 \pm 7 stems ha ${ }^{-1}$; and $50 \%$ thinning (heavy thinning, HT) with tree stem density adjusted to $1089 \pm 3$ stems ha $^{-1}$. The trees that were cut for thinning were removed from the plots, but the understory shrub and herb layers remained untouched. The dominant overstory vegetation in all stands was 35 years old L. principis-rupprechtii. Shrub species included Elaeagnus umbellata and Rubus parvifolius. Herbaceous species included Carex rigescens and Dendranthema chanetii. Detailed treatment characteristics are presented in Tables 12.

\subsection{Sampling and chemical analysis}

Total soil carbon and nitrogen concentration were determined from soil samples collected from treatments at $0-10 \mathrm{~cm}, 10-20 \mathrm{~cm}, 20-30 \mathrm{~cm}, 30-40 \mathrm{~cm}$, and $40-50 \mathrm{~cm}$ depths using a cylindrical soil auger. Samples were collected at three times during the 2015 growing season: spring, summer and autumn. Snow cover and freezing 
109

110

111

112

113

114

prevented collection of soil samples in the winter. Soil samples were collected from nine randomly chosen locations within each quadrat and then combined according to depth to form one homogenous composite sample per depth. Visible stones and organic residues were removed and each sample was sieved through a 2-mm mesh prior to chemical analyses. After sifting, each composite soil sample was divided into two subsamples. One subsample was stored in a $4^{\circ} \mathrm{C}$ incubator until DON and MBN concentration could be determined. The second sample was air-dried and passed through a $0.25-\mathrm{mm}$ sieve before determining soil organic carbon (SOC) concentration and STN concentration. Then it was passed through a 2-mm sieve for soil $\mathrm{pH}$.

SOC and STN concentrations were determined by dry combustion using an elemental analyzer (Thermo Scientific FLASH $2000 \mathrm{CHNS} / \mathrm{O}$, USA). The MBN concentration was measured using an $\mathrm{HCl}_{4}$-fumigation extraction technique; $10.0 \pm 0.5 \mathrm{~g}$ of fresh soil was fumigated with $\mathrm{HCl}_{4}$, then extracted with $40 \mathrm{~mL}$ of $0.5 \mathrm{~mol} \cdot \mathrm{L}^{-1}$ $\mathrm{K}_{2} \mathrm{SO}_{4}$, shaken for $1 \mathrm{~h}$ at $350 \mathrm{r} \mathrm{min}^{-1}$, and filtered through a $0.45 \mu \mathrm{m}$ membrane after centrifuging $5 \mathrm{~min}$ at 3000 $\mathrm{r} \mathrm{min}^{-1}$. The filtrate concentration was quantified using a total organic carbon analyzer (Multi N/C 3000, Germany). The DON concentration was measured as the carbon concentration of non-fumigated soil samples (Boyer and Groffman 1996).

MBN was calculated as:

$$
\begin{aligned}
& \qquad \mathrm{MBN}=\mathrm{EC} / \mathrm{k}_{\mathrm{EC}} \\
& \text { In (1) } \mathrm{E}_{\mathrm{C}}=\text { (organic } \mathrm{N} \text { extracted from fumigated soils) }- \text { (organic } \mathrm{N} \text { extracted from non-fumigated soils) } \\
& \text { and } \mathrm{k}_{\mathrm{EC}}=0.54
\end{aligned}
$$

The soil texture was analyzed using the pipette method (Gee and Bauder, 1986). Air-dried soil samples that had been passed through a 1-mm sieve were used for soil $\mathrm{pH}$ determination. Using a $\mathrm{pH}$ meter (Sartorius PB- 
129

130

131

10), $\mathrm{pH}$ was determined for a 1:2.5 soil-water mixture. Gravimetric soil water concentration was measured as mass lost after drying for $24 \mathrm{~h}$ at $105^{\circ} \mathrm{C}$. Meteorological data was collected from a small fixed weather station beside the sample area.

\subsection{Environmental factors in the density adjustment plots}

Soil respiration was measured with an LI-8100 soil $\mathrm{CO}_{2}$ flux system (LI-COR Inc., NE., USA) in the middle and at the end of each month during the three sampling seasons. Measurements were taken on twelve PVC collars in each plot during 10:00-17:00 h over a one-day period. The PVC collars in each plot were systematically arranged. Soil temperature and volumetric soil water content at $5 \mathrm{~cm}$ depth were concurrently measured near each PVC collar. Each PVC collar is $10 \mathrm{~cm}$ in diameter and $5 \mathrm{~cm}$ in height, inserted $3 \mathrm{~cm}$ below the surface of the soil.

Soil respiration was calculated as the average values measured twice each month during the vegetation growing season and the computation formula is as follows:

$$
C_{R S}=\frac{R_{S} \cdot t \cdot C_{m o l}}{10^{6}}
$$

$C_{R S}$ (total carbon emission from soil respiration) $\mathrm{gC} \cdot \mathrm{m}^{-2} ; R_{S}$ (Soil respiration), $\mu \mathrm{mol} \cdot \mathrm{m}^{-2} \cdot \mathrm{s}^{-1} ; \mathrm{t}($ time), $\mathrm{s}$;

$\mathrm{C}_{\mathrm{mol}}, 12 \mathrm{~g} \cdot \mathrm{mol}^{-1} \cdot \mathrm{C}_{R S}$ in winter in this study accounted for $10 \%$ of the total carbon emissions from annual soil respiration (Wang, et al., 2002).

The forest light environment measurements were collected in July 2015 and 2016. The canopy analyzer (WIN SCANOPY 2010 a, Canada) was used to measure total PPFD over: photosynthetic photon flux density over the forest and total PPFD under: photosynthetic photon flux density under the forest. The plot was divided into three areas, left, middle and right, each of which was divided into three sub areas, for a total of nine areas. 
149 The canopy analyzer was set up in the center of each sub area. Optical information was collected and the

150 instrument software was used to analyze stand light environment (PPFD) back in the laboratory.

151

152

153

154

155

156

157

158

160

\subsection{Statistical Analysis}

SPSS 20.0 (IBM, Chicago, USA) and R were used for statistical analyses. All data in the tables and figures are presented as means ( $\mathrm{n}=15,3$ plot repeats $* 5$ soil depths). A mixed-effects model was used to consider the relationships between year, season and treatment. To improve the representativeness of the samples, we used the mean value of each soil property, averaging the values from each of the five layers, to represent the content of each value in the plot, based on the post hoc Tukey-HSD test using SPSS. One-way analysis of variance was used to examine the impact of thinning treatment in a certain season by the T-test, using SPSS. The least significant difference (LSD) test was used to compare treatment means, with significant effects having $\mathrm{p}<0.05$.

To examine the relationship between soil chemical variables, the data was pooled from the depths of 10-20, 20$30,30-40$ and $40-50 \mathrm{~cm}$, the six sampling seasons and the twelve independent plots $(\mathrm{n}=360)$, and was examined for Pearson relationships using R and the "Performance Analytics" package for the data visualization.

\section{Results}

\subsection{General environmental characteristics}

The meteorological data recorded by an automatic meteorological station indicated that precipitation was significantly higher in the summer than in the spring or autumn. Both the air temperature and the $0-10 \mathrm{~cm}$ soil temperature were also highest in summer. In 2016, precipitation was 1.3 times greater than in 2015 (Fig. 1). 
soil among the different thinning treatments (Table 1). With greater tree stem density reduction, or thinning, the

169

171

172

173

176

177

forest understory became much brighter from both direct and scattered light as well as total radiation. The total

photosynthetic photon flux density (PPFD under) in the understory increased in the LT, MT and HT treatments, with respect to the control ( $p<0.05$; Table 2). Soil respiration was higher in the MT plots, but not significantly.

The higher soil temperature measured in MT only differed from the other treatments significantly in 2015. Soil moisture was only significantly higher than CK in HT (Table 2).

The total biomass gradually decreased with increased thinning. The variance analysis showed that this difference was only significant between the CK and HT treatments $(\mathrm{p}<0.05)$ (Table 3).

The understory species composition was relatively simple in this L. principis-rupprechtii plantation, with the understory vegetation in the CK containing nine families, 13 genera and 14 herbaceous species. Dominant plants included species of the Compositae, Ranunculaceae and Rosaceae families. In the plots undergoing thinning treatments, understory plant species richness increased with decreasing tree stem density. Overall, the highest species richness was recorded in the MT treatment (Table S2). Soil nutrients decreased significantly with soil depth and generally accumulated to higher levels as the summer progressed (Table S2).

\subsection{Soil total nitrogen}

Tree stem density effects on STN were significant in five sampling seasons out of six, (Fig. 2a). In both 2015 and 2016, a significantly higher summer STN was measured in the MT than the LT and the CK. STN was analyzed separately in each season. In spring $2015(\mathrm{p}=0.0027),\left(\mathrm{g} \mathrm{N} \mathrm{Kg}^{-1}\right)$ : MT $(3.1 \pm 0.21)>\mathrm{HT}(2.9 \pm 0.33)$

$>\mathrm{CK}(2.5 \pm 0.05)>\mathrm{LT}(2.3 \pm 0.11 \mathrm{~g})$. In summer $2015(\mathrm{p}=0.002),(\mathrm{g} N \mathrm{Kg}-1)$ : MT $(3.6 \pm 0.04)>\mathrm{HT}(3.4 \pm$ 
$1870.21)>\operatorname{LT}(2.9 \pm 0.08)>\operatorname{CK}(2.7 \pm 0.19)$. In autumn $2015(\mathrm{p}=0.110),(\mathrm{g} N \mathrm{Kg}-1):$ HT $(3.2 \pm 0.42)>\mathrm{MT}(3.1$

$188 \pm 1.197)>\mathrm{CK}(2.7 \pm 0.29)>\mathrm{LT}(2.5 \pm 0.97)$. Thus, STN was highest in spring and summer in the MT treatment, compared to other treatments. Mean STN concentrations were 25\% higher in the MT (30\% thinning) and HT (50\% thinning) treatments than in the less severe thinning treatments (i.e. LT - 15\% thinning, and CK - $0 \%$

191 thinning).

In 2016, the response of STN content to density adjustment was similar to 2015, but there were bigger differences between the HT and MT treatments and the LT and CK treatments. In 2016, the tree stem density effects on STN were significant in spring $(p=0.003)$, summer $(p=0.026)$ and autumn $(p=0.003)$. Across the three sampling seasons, $\left(\mathrm{g} \mathrm{N} \mathrm{Kg}^{-1}\right)$ : MT $(3.2 \pm 0.44)>\mathrm{HT}(2.8 \pm 0.23)>\mathrm{CK}(2.4 \pm 0.24)>\mathrm{LT}(2.3 \pm 0.13)$.

Accumulation of STN content was greater for the treatments with more thinning (MT, HT) than the treatments with less thinning $(\mathrm{CK}, \mathrm{LT})$ in both sampling years, resulting in $26.1 \%, 24.9 \%$, and $22.5 \%$ increases between less thinned and more thinned treatments in spring, summer and autumn, respectively, in 2015 (Fig. 3a) and resulting in $12.5 \%, 26.3 \%$, and $48.9 \%$ increases between less thinned and more thinned treatments in spring, summer and autumn, respectively, in 2016 (Fig. 3b).

\subsection{Soil nitrogen components}

Interaction effects among treatment, sampling season and year were found $(\mathrm{p}=0.017)$ for DON (Table 4).

Seasons and the two sampling years affected DOC more significantly $(\mathrm{p}<0.001)$ than treatment with either additional variable. The soil in 2015 accumulated more DON overall than in 2016 and significantly more DON accumulated during summer 2015 than in any other season (Fig. 3a). Tree stem density had little effect on dissolved organic nitrogen (DON) in the soil across the sampling seasons. However, DON varied significantly 
with the seasons $(p<0.001)$, changing rapidly over the sampling period. The DON was $102.7 \%$ higher in summer

than in the other seasons.

The microbe biomass nitrogen, which reflects the microbial activity of forest soils, was highest in the MT

treatment across all seasons $(p=0.012$ in spring; $p=0.076$ in summer; $p=0.035$ in autumn $)$ in 2015 . The mixed-

effects model indicated no interaction effects among treatment, sampling season and year $(p=0.331)$ for MBN.

However, the interaction between season and year affected MBN significantly $(p<0.001$; Table 4$)$. The soil in

in the HT treatment $\left(\mathrm{mg} \mathrm{N} \mathrm{kg}^{-1}\right)$ : in spring, $\mathrm{CK}<\mathrm{HT}(7.7 \pm 0.79)<\mathrm{LT}(8.8 \pm 1.16)<\mathrm{MT}(10.8 \pm 0.30)$; in

summer, CK $(29.9 \pm 2.49)<\mathrm{LT}(30.5 \pm 1.32))<\mathrm{HT}(32.2 \pm 2.97)<\mathrm{MT}(36.4 \pm 0.93)$; and in autumn, LT $(30.2$

$\pm 0.80)<\mathrm{HT}(33.0 \pm 0.51)<\mathrm{CK}(30.7 \pm 3.37)<\mathrm{MT}(35.8 \pm 0.44)$. However, in 2016, MBN was not significantly

affected by density adjustment ( $p=0.165$ in spring; $p=0.555$ in summer; $p=0.205$ in autumn). In summer

2016, a significantly higher MBN was measured, which was $302.6 \%$ higher than the average MBN content

across all the seasons and treatments.

\subsection{Relationships among soil nitrogen components}

3b, Fig. 4b). No significant interaction effects were found among treatment, sampling season and year

individually $(\mathrm{p}=0.302)$ for DON/STN. However, season and year interacted to affect DON/STN $(\mathrm{p}<0.001)$. The 

treatment, and then increased in the HT treatment (Fig. 3b) (\%): spring 2015 (p=0.027), MT $(1.42 \pm 0.13)<\mathrm{CK}$

$(1.59 \pm 0.05)<\mathrm{LT}(1.73 \pm 0.08)<\mathrm{HT}(1.78 \pm 0.04)$; summer $2015(\mathrm{p}=0.003)$, MT $(6.13 \pm 0.16)<\mathrm{CK}(6.58 \pm$

$0.20)<$ LT $(7.79 \pm 0.34)<$ HT $(8.47 \pm 0.76)$; autumn 2015, not significant $(\mathrm{p}=0.10) ;$ spring $2016(\mathrm{p}=0.123)$

summer $2015(\mathrm{p}=0.047)$, MT $(2.70 \pm 0.43)<$ HT $(3.22 \pm 0.91)<\mathrm{CK}(4.18 \pm 0.16)<\mathrm{LT} 4.51 \pm 0.55)$; autumn

DON/STN reached its minimum in the MT plot. For MBN/STN, a significant interaction effect was found among

$\mathrm{p}<0.001, \mathrm{n}=360$; Fig. 5).

\section{Discussion}

The specific objectives of this study were to determine how STN varies with stand tree stem density in a $L$.

principis-rupprechtii plantation and how variation in each soil nitrogen component may drive patterns in STN. 
tree stem removal), then decreasing in HT (50\% removal), which indicates that thinning generally leads to

increased soil total nitrogen. However, this effect was limited to the growing season and was not seen in autumn.

247

248

\subsection{Environmental factors effect on the soil $\mathrm{N}$ pool}

The availability of soil $\mathrm{N}$ is widely regarded as a factor commonly restricting primary productivity (Sigurdsson, 2001) and the function of certain biochemical processes (Vitousek et al, 2010). Similarly, an experiment that followed mixed forests for twelve years after thinning showed that tree stem density reduction can significantly improve the growth of woody species in stands (Lei, 2005). Studies in Picea abies (Heinrichs and Schmidt, 2009) and Pseudotsuga menziesii forests (Ares et al. 2010) also found that both forest species richness and the abundance of shrub and grass species increases with thinning intensity. Aboveground vegetation is one of the main sources for the soil N (nitrogen) pool (Achat et al. 2015), hence changes in species composition and biomass may affect STN. As we found here, understory plant species were most abundant in the moderate thinning treatment (MT, Table S1). More understory biomass was found in plots that had undergone a more intense thinning treatment (Table 3), echoing the higher values of STN and SOC, also in the MT plots.

The forest density adjustment conducted in the L. principis-rupprechtii plantation altered the environmental factors both at all layers (light condition, soil respiration, temperature and moisture) in the soil, which may also contribute to the difference in the soil $\mathrm{N}$ pool. Light and space availability in the understory can change with thinning (Richards and Hart, 2011; Roberts, 2004; Table 1). Here, thinning treatments altered the total PPFD under and had no impact on the total PPFD over (Table 2). Other crucial environmental factors like soil temperature and soil respiration changed with density adjustments. Higher soil temperatures and soil respiration 
265

266

precipitation in 20161.3 times higher than 2015 (Fig. 1), which may also explain the significant difference in soil respiration between the two years.

The higher soil temperatures in MT throughout the entire growing season suggests that this important environmental factor (Ma et al., 2010) may be directly affect by moderate thinning. The soil under MT received more radiation, the main energy source, than CK and LT. As for HT, the intensive 50\% thinning may have led to the reduction in ground litter, thus scattering the heat to the atmosphere. Soil moisture was enhanced significantly by the treatment, with the increase in thinning leading to a higher soil moisture content (Table 2).

According to the intermediate disturbance hypothesis (Fox, 1979; Roxburgh et al. 2004; Huston 2014), moderate rates of disturbance to plant communities can maintain high species diversity. This was observed on an experimental Cupressus funebris plantation, where moderate thinning enhanced the diversity indices of both understory shrub and herbaceous species (Gong et al. 2015). Combinations of various environmental factors, such as understory plant species composition and light and space availability, may alter the soil environment to different extents, thus affecting STN concentrations.

Close relationships were found between STN and other soil properties. Plotting all the data across treatment and season, higher STN concentrations are shown to correspond to higher concentrations of SOC, DON, DOC and MBN (Fig. 5). Bravo-Oviedo et al. (2015) and further analysis performed in this study revealed that density treatments affect various components of the soil $\mathrm{N}$ pool, which are considered to be factors driving variation in total soil N.

\subsection{Effect of Nitrogen components on the soil $\mathrm{N}$ pool}


the environmental factors in the forests and $\mathrm{b}$ ) the soil $\mathrm{N}$-components and the solubility of the $\mathrm{N}$ pool.

microbial activity and STN concentration (Iqbal et al. 2010; Aerts et al. 2012). Even though there was no

significant correlation found between tree stem density and DON, the thinning treatments were found to alter

soil nitrogen characteristics, with one unit of STN containing less DON in the more extreme thinning treatments

(Fig. 3b). The amount of DON can affect STN dynamics, as a higher DON/STN means a greater possibility of

nitrogen loss through leaching, which would affect nitrogen accumulation rates. The DON/STN ratio was

affected significantly by thinning treatment $(\mathrm{p}<0.001$, Table 3$)$ and was at its minimum in MT plots (Fig. 3b),

the same treatment where the highest concentrations of STN were recorded in spring and summer 2015 and expectations, however DON alone did not. 
304 also greater in the summer (Fig. 1). Microbial growth can expand in the presence of increased temperatures

305 (Edwards et al. 2006), which can then be further facilitated by higher concentrations of DON, providing more

306 nitrogen for the microbes (Iqbal et al. 2010). In this study a close positive relationship was measured between

307 DON and MBC $(R=0.657, p<0.001, n=360$; Fig. 5). Increased precipitation has been reported to be an

important factor affecting the $\mathrm{N}$ pool (Yu et. al, 2017) and the resulting nitrogen (DON) losses from summer to

autumn might explain the STN reduction in autumn. This confirms the hypothesis that moderate thinning reduces

the DON/STN ratio, thus, enhancing the STN (Fig. 2a; Fig. 3b). treatment. 
SOC/STN (Fig. 4c) were observed in the MT treatment, suggesting that microbes might have been more active

under intermediate tree stem densities.

\section{Conclusions}

Clear effects of thinning treatments were found on STN in a Larix principis-rupprechtii plantation three

years after thinning. The STN concentration was greatest in the MT plots. Moderate thinning treatments may

of the soil $\mathrm{N}$ pool. The influence of the thinning treatments on the $\mathrm{N}$ pool are likely driven by the effect of stem 
343 STN accumulation. The environmental factors of soil temperature, soil moisture and light moderated conditions

344 to be better for microorganisms and the plants, which also contribute to the STN accumulation. We recommend

345

346

347

348

349

350

351

352

353

354

355

356

357

358

359

360

361

362

363

364

365

366

367

moderate thinning (1404 trees per ha) of L. principis-rupprechtii plantations to promote $\mathrm{N}$ retention and we agree

with the intermediate disturbance hypothesis, but suggest that long-term studies are still required to validate

these findings.

\section{Acknowledgments}

We gratefully acknowledge support from the Taiyue Forestry Bureau and the Haodifang Forestry Centre for fieldwork. We also thank all those who provided helpful suggestions and comments on improving the quality of this manuscript. We would also like to thank Elizabeth Tokarz at the Yale University for her assistance with English language and grammatical editing of the manuscript.

\section{References}

Adrian A, Andrewr N, Klausj P. 2010. Understory abundance, species diversity and functional attribute response to thinning in coniferous stands. Forest Ecology \& Management 260:1104-1113 DOI: 10.1016/j.foreco.2010.06.023

Aerts R, Bodegom PMV, Cornelissen JHC. 2012. Litter stoichiometric traits of plant species of high-latitude ecosystems show high responsiveness to global change without causing strong variation in litter decomposition. New Phytologist 196:181-188 DOI: 10.1111/j.1469-8137.2012.04256.x ·

Boyer JN, Groffman PM. 1996. Bioavailability of water extractable organic carbon fractions in forest and agricultural soil profiles. Soil Biology \& Biochemistry 28:783-790 DOI: 10.1016/0038-0717(96)00015-6

Bravooviedo A. 2015. Forest thinning impact on carbon stock and soil condition in Southern European populations of $P$. sylvestris L. Forest Ecology \& Management 357:259-267 DOI: 10.1016/j.foreco.2015.08.005

Canadell JG, Raupach MR. 2008. Managing forests for climate change mitigation. Science 320:1456-7

Cleveland CC, Liptzin D. 2007. C:N:P stoichiometry in soil: is there a "Redfield ratio" for the microbial biomass? Biogeochemistry 85:235- 252 DOI 10.1007/s10533-007-9132-0 
368

369

370

Crow TR, Buckley DS, Nauertz EA. 2002. Effects of management on the composition and structure of northern hardwood forests in upper Michigan. Forest Science 48:129-145.

Deng Q, Cheng X, Yang Y. 2014. Carbon-nitrogen interactions during afforestation in central China. Soil Biology \& Biochemistry 69:119-122 DOI:10.1007/s10533-007-9132-0

Dixon RK, Solomon AM, Brown S. 1994. Carbon pools and flux of global forest ecosystems. Science 263:18590

Duan J, Ma LY, Jia LYM, Jia Z, Gong N, Che W. 2010. Effect of thinning on Platycladus orientalis plantation and the diversity of undergrowth vegetation. Acta Ecologica Sinica 30:1431-1441.

Edwards KA, Mcculloch J, Kershaw GP. 2006. Soil microbial and nutrient dynamics in a wet Arctic sedge meadow in late winter and early spring. Soil Biology \& Biochemistry 38:2843-2851 DOI:10.1016/j.soilbio.2006.04.042

Fox JF. 1979. Intermediate-disturbance hypothesis. Science 204:1344-1345.

Ge SF, Xu HG, Ji MM, Jiang YM. 2013. Effects of soil C:N on growth and distribution of nitrogen and carbon of Malus hupehensis seedlings. Journal of Plant Ecology 37:942- 949 DOI: 10.3724/SP.J.1258.2013.00097

Gee GW, Bauder JW. 1986. Particle size analysis. In: Klute, A. (Ed.), Methods of Soil Analysis, Part I. second ed. American Society of Agronomy Inc, Madison.

Gong GT, Niu M, Mu CL. 2015. Impacts of different thinning intensities on growth of cupressus funebris plantation and understory plants. Scientia Silvae Sinicae 51:8-15 DOI: 10.11707/j.1001-7488.20150402

Gravel DC, Beaudet M, Messier C. 2010. Shade tolerance, canopy gaps and mechanisms of coexistence of forest trees. Oikos 119:475-484 DOI: 10.1111/j.1600-0706.2009.17441.x 
388

389

390

391

392

393

394

395

396

397

398

Guan FY, Tang XL, Fan SH, Zhao JC, Peng C. 2015. Changes in soil carbon and nitrogen stocks followed the conversion from secondary forest to Chinese fir and Moso bamboo plantations. Catena 133:455- 460. DOI:10.1016/j.catena.2015.03.002

Hafner SD, Groffman PM. 2005. Soil nitrogen cycling under litter and coarse woody debris in a mixed forest in New York State. Soil Biology \& Biochemistry 37:2159-2162. DOI 10.1016/j.soilbio.2005.03.006

Hargreaves PR, Brookes PC, Gjs R, Poulton PR. 2003. Evaluating soil microbial biomass carbon as an indicator of long-term environmental change. Soil Biology \& Biochemistry 35:401- 407.

He Y, Zhou YG, Li XW. 2013. Seasonal dynamics of soil microbial biomass carbon in Alnus formosana forestgrass compound models. Scientia Silvae Sinicae 49:26-33. DOI:10.11707/j.1001-7488.20130704

Heinrichs S, Schmidt W. 2009. Short-term effects of selection and clear cutting on the shrub and herb layer vegetation during the conversion of even-aged Norway spruce stands into mixed stands. Forest Ecology \& Management 258:667-678 doi:10.1016/j.foreco.2009.04.037

Houghton RA. 1995. Land-use change and the carbon cycle. Global Change Biology 1995:1, 275-287.

Huston MA. 2014. Disturbance, productivity and species diversity: empiricism vs. logic in ecological theory. Ecology 95:2382-2396.

Iqbal J, Hu R, Feng M, Lin S, Malghani S, Ali IM. 2010. Microbial biomass, and dissolved organic carbon and nitrogen strongly affect soil respiration in different land uses: A case study at Three Gorges Reservoir Area, South China. Agriculture, Ecosystems \& Environment 137:294-307. DOI: 10.1016/j.agee.2010.02.015 
407 IUSS Working Group WRB. 2006. World reference base for soil resources 2006. World Soil Resources 408 Reports 103, 2nd edition. FAO, Rome.

409

410

411

412

413

414

416

417

418

419

420

421

422

423

424

425

Jackson SM, Fredericksen TS, Malcolm JR. 2002. Area disturbed and residual stand damage following logging in a Bolivian tropical forest. Forest Ecology \& Management 166:271-283.

Jandl R, Lindner M, Vesterdal L, Bauwens B, Baritz R, Hagedorn F. 2007. How strongly can forest management influence soil carbon sequestration? Geoderma 137:253-268. DOI:10.1016/j.geoderma.2006.09.003

Jessica KA, Deborah LM, George WT. 2007. Changes in understory vegetation and soil characteristics following silviculture activities in a southeastern mixed pine forest. Journal of the Torrey Botanical Society 134:489-504. DOI:10.3159/07-RA-013.1

Jiang YM, Chen CR, Liu YQ. 2010. Soil soluble organic carbon and nitrogen pools under mono- and mixed species forest ecosystems in subtropical China. Journal of Soils \& Sediments 10:1071-1081 DOI: $10.1007 / \mathrm{s} 11368-010-0191-9$

Jones DL, Hughes LT, Murphy DV. 2009. Dissolved organic carbon and nitrogen dynamics in temperate coniferous forest plantations. European Journal of Soil Science 59:1038-1048 DOI: 10.1111/j.13652389.2008.01077.x

Karlsson A, Alberktson A, Elfving B. 2002. Development of Pinus sylvestris main stems following three different precommercial thinning methods in a mixed stand. Scandinavian Journal of Forest Research 17:256-262 DOI: $10.1080 / 028275802753742927$ 
426

427

428

429

430

431

432

433

434

435

436

437

438

439

440

441

442

443

444

445

446

447

448

Lähde E, Laiho O, Norokorpi Y, Saksa T. 2002. Development of Norway spruce dominated stands after single-tree selection and low thinning. Canadian Journal of Forest Research 32:1577-1584 DOI: 10.1139/X02-075

Lal R. 2004. Soil carbon sequestration impacts on global climate change and food security. Science 304:1623 DOI: $10.1126 /$ science. 1097396

Lehrsch GA, Sojka RE, Koehn AC. 2012. Surfactant effects on soil aggregate tensile strength. Geoderma 189:199-206 DOI: 10.1016/j.geoderma.2012.06.015

Lei X. 2005. Effects of thinning on mixed stands of Larix olgensis, Abies nephrolepis and Picea jazoensis. Scientia Silvae Sinicae 41:78-85. DOI: 10.11707/j.1001-7488.20050414

Li D, Niu S, Luo Y. 2012. Global patterns of the dynamics of soil carbon and nitrogen stocks following afforestation: a meta-analysis. New Phytologist 195:172 DOI: 10.1111/j.1469-8137.2012.04150.x

Li M, Zhou X, Zhang Q, Cheng X. 2014. Consequences of afforestation for soil nitrogen dynamics in central china. Agriculture Ecosystems \& Environment 183:40-46 DOI: 10.1016/j.agee.2013.10.018

Liu B. 2010. Changes in soil microbial biomass carbon and nitrogen under typical plant communies along an altitudinal gradient in east side of Helan Mountain. Ecology \& Environmental Sciences 19:883-888.

Ma S, Concilio A, Oakley BB, North MP, Chen J. 2010. Spatial variability in microclimate in a mixed-conifer forest before and after thinning and burning treatments. Forest Ecology and Management 259:904-915 DOI: $10.1016 /$ j.foreco.2009.11.030

Mcguire AD, Melillo JM, Joyce LA. 1995. The role of nitrogen in the response of forest net primary production to elevated atmospheric carbon dioxide. Annual Review of Ecology \& Systematics 26:473-503 DOI: 10.1146/annurev.es.26.110195.002353

Miles L, Kapos V. 2008. Reducing greenhouse gas emissions from deforestation and forest degradation: global land-use implications. Science 320, 1454-1455 DOI: 10.1126/science.1155358 
Pariona W, Fredericksen TS, Licona JC. 2003. Natural regeneration and liberation of timber species in logging gaps in two Bolivian tropical forests. Forest Ecology \& Management 181:313-322 DOI: $10.1016 / \mathrm{S} 0378-1127(03) 00002-1$

Rastetter EB, Ågren GI, Shaver GR. 1997. Responses of n-limited ecosystems to increased $\mathrm{CO}_{2}$ : a balancednutrition, coupled-element-cycles model. Ecological Applications 7:444-460 DOI: 10.2307/2269511

Ren C, Sun P, Kang D. 2016. Responsiveness of soil nitrogen fractions and bacterial communities to afforestation in the Loess Hilly Region (LHR) of China. Scientific Reports 6:28469 DOI: 10.2307/2269511

Richards JD, Hart JL. 2011. Canopy gap dynamics and development patterns in secondary Quercus, stands on the Cumberland Plateau, Alabama, USA. Forest Ecology \& Management 262:2229-2239 DOI: 10.1016/j.foreco.2011.08.015

Roberts MR. 2004. Response of the herbaceous layer to natural disturbance in North American forests. Canadian Journal of Botany 82:1273-1283 DOI: 10.1139/b04-091

Roxburgh SH, Shea K, Wilson JB. 2004. The intermediate disturbance hypothesis: Patch dynamics and mechanisms of species coexistence. Ecology 85:359-371 http://www.jstor.org/stable/3450202

Schulten HR, Schnitzer M. 1997. The chemistry of soil organic nitrogen: a review. Biology \& Fertility of Soils 26:1-15 DOI: $10.1007 / \mathrm{s} 003740050335$

Sigua G, Coleman S. 2006. Sustainable management of nutrients in forage-based pasture soils: effect of animal congregation sites (5 pp). Journal of Soils \& Sediments 6:249-253 DOI: 10.1065/jss2006.09.182

Sigurdsson BD. 2001. Environmental control of carbon uptake and growth in a Populus trichocarpa plantation in Iceland. Swedish Univ.of Agricultural Sciences Uppsala. faculty of Forestry. 
469

470

471

472

473

474

475

476

477

478

479

480

481

482

483

484

485

486

487

488

Smith DM, Larson BC, Kelty MJ, Ashton PMS. 1997. The practice of silviculture: applied forest ecology. Wiley

Springob G, Kirchmann H. 2003. Bulk soil $\mathrm{C}$ to $\mathrm{N}$ ratio as a simple measure of net $\mathrm{N}$ mineralization from stabilized soil organic matter in sandy arable soils. Soil Biology \& Biochemistry 35:629-632 DOI: 10.1016/S0038-0717(03)00052-X

Stockmann U, Adams MA, Crawford JW. 2013. The knowns, known unknowns and unknowns of sequestration of soil organic carbon. Agriculture Ecosystems \& Environment 164:80-99 DOI : /10.1016/j.agee.2012.10.001

Tateno M, Chapin FS. 1997. The logic of carbon and nitrogen interactions in terrestrial ecosystems. American Naturalist 149:723-744.

Townsend AR, Braswell BH, Holland EA. 1996. Spatial and Temporal Patterns in Terrestrial Carbon Storage Due to Deposition of Fossil Fuel Nitrogen. Ecological Applications 6:806-814.

Vitousek PM, Porder S, Houlton BZ, Chadwick OA. 2010. Terrestrial phosphorus limitation: mechanisms, implications, and nitrogen-phosphorus interactions. Ecological Applications 20:5-15. DOI: 10.1890/080127.1

Wang J, Zhuang S, Zhu Z. 2017. Soil organic nitrogen composition and mineralization of paddy soils in a cultivation chronosequence in China. Journal of Soils \& Sediments 17:1588-1598 DOI 10.1007/s11368$016-1629-5$

Wardle, D.A., 1992. A comparative assessment of factors which influence microbial biomass carbon and nitrogen levels in soil. Biological Reviews 67:321-358. 
489

490

492

493

494

495

496

497

498

499

Wieder WR, Cleveland CC, Taylor PG, Nemergut DR, Hinckley EL, Philippot L. 2013. Experimental removal and addition of leaf litter inputs reduces nitrate production and loss in a lowland tropical forest. Biogeochemistry 113:629-642 DOI: 10.1007/s10533-012-9793-1

Yi Z, Fu S, Yi W. 2007. Partitioning soil respiration of subtropical forests with different successional stages in south China. Forest Ecology \& Management 243:178-186 DOI: 10.1016/j.foreco.2007.02.022

Yu Y, Wei W, Chen L. 2017. Land preparation and vegetation type jointly determine soil conditions after longterm land stabilization measures in a typical hilly catchment, Loess Plateau of China. Journal of Soils \& Sediments 17:144-156.

Zhang CH, Wang ZM, Ju WM, Ren CY. 2011. Spatial and temporal variability of soil C/N ratio in Songnen plain maize belt. Journal of Soils \& Sediments 17:144-156.

Zhao J, Chen S, Hu R. 2017. Aggregate stability and size distribution of red soils under different land uses integrally regulated by soil organic matter, and iron and aluminum oxides. Soil \& Tillage Research 167:7379 DOI: $10.1016 /$ j.still.2016.11.007

Zhong Z, Makeschin F. 2006. Differences of soil microbial biomass and nitrogen transformation under two forest types in central Germany. Plant \& Soil 283:287-297 DOI 10.1007/s11104-006-0018-z

Zou XM, Ruan HH, Fu Y. 2005. Estimating soil labile organic carbon and potential turnover rates using a sequential fumigation-incubation procedure. Soil Biology \& Biochemistry 37:1923-1928 DOI:10.1016/j.soilbio.2005.02.028 
Figure 1

Air temperature, $10 \mathrm{~cm}$ soil temperature and average precipitation in the study treatments in 2015 and 2016.

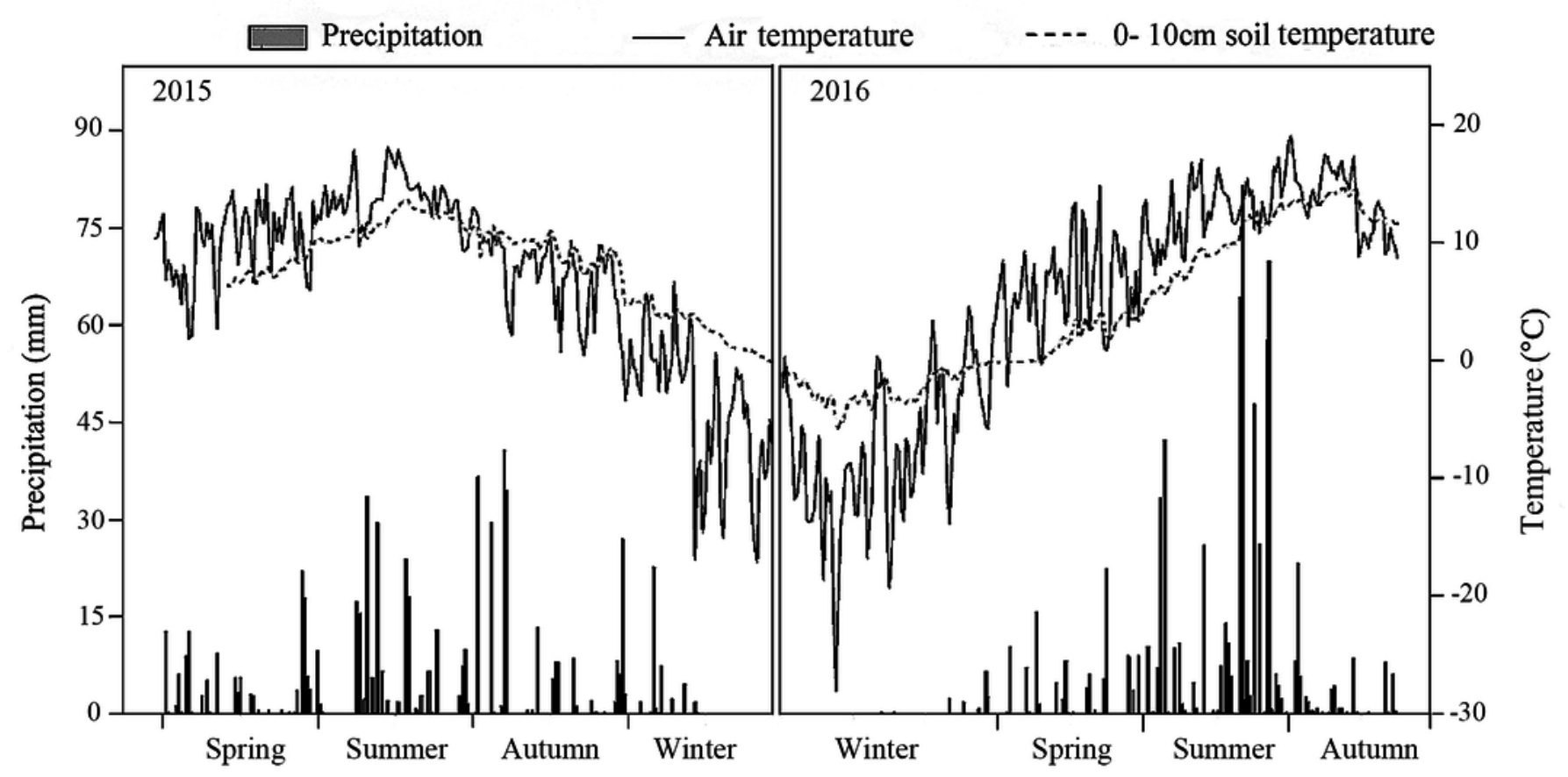




\section{Figure 2}

Variation in the STN (a) and SOC (b) in different thinning treatments across the growing seasons in 2015 and 2016.

CK, the no thinning, control treatments. LT, the low thinning treatments ( $15 \%$ thinning). MT, the moderate thinning sample treatments (35\% thinning). HT, the heavy thinning sample treatments (50\% thinning). STN, soil total nitrogen; SOC, soil total organic carbon. Each bar represents an average value across three replicate samples $(n=15)$, i.e. three plots repeats $\times$ five soil depths. Error bars represent standard errors around the three plot repeats.

Different lowercase letters demarcate a significant difference among different density adjustments within the same sampling season $(p<0.05)$. The same for Figure 3,4 and 5 .
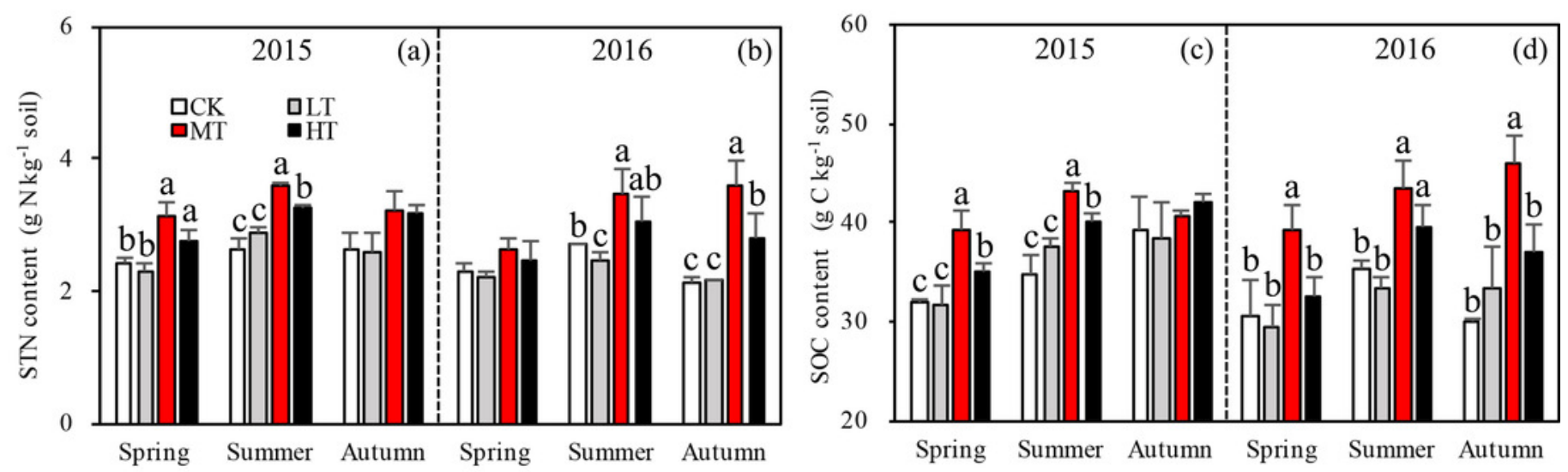


\section{Figure 3}

Variation in the DON (a) and DON/STN (b) in different thinning treatments across the growing seasons.

CK, the no thinning, control treatments. LT, the low thinning treatments (15\% thinning). MT, the moderate thinning sample treatments ( $35 \%$ thinning). $\mathrm{HT}$, the heavy thinning sample treatments (50\% thinning). DON, dissolved organic nitrogen; STN, soil total nitrogen. Each bar represents an average value across three replicate samples $(n=15)$, i.e. three plots repeats $x$ five soil depths. Error bars represent standard errors around the three plot repeats. Different lowercase letters demarcate a significant difference among different density adjustments within the same sampling season $(p<0.05)$.
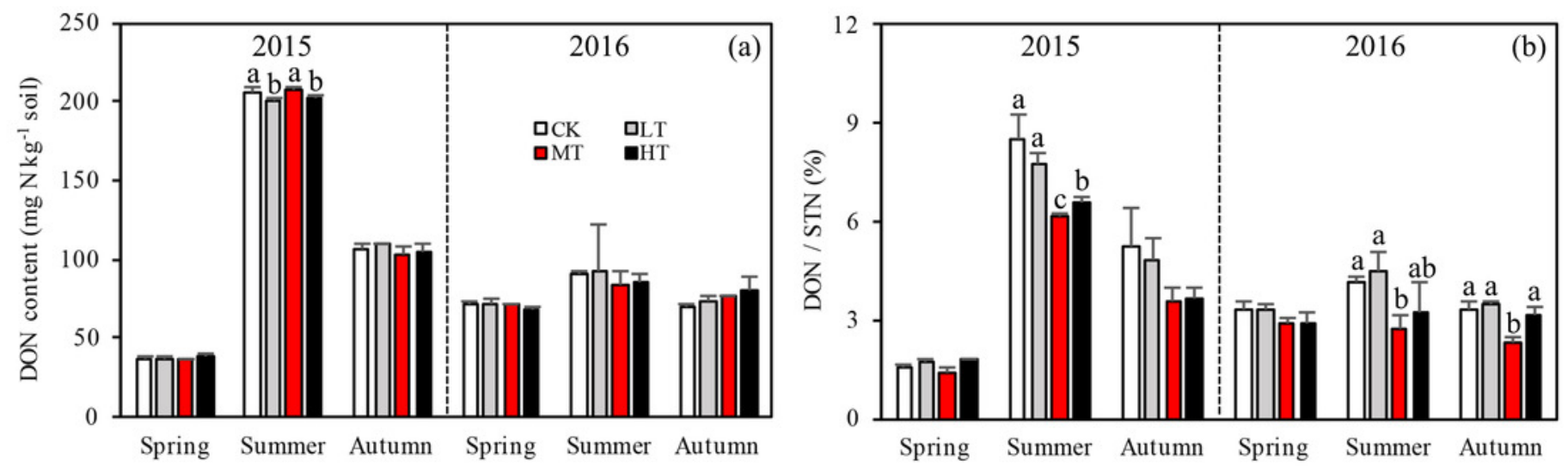


\section{Figure 4}

Variation in the MBN (a), MBN/STN (b) and SOC/STN (c) in different thinning treatments across the growing seasons.

CK, the no thinning, control treatments. LT, the low thinning treatments ( $15 \%$ thinning). MT, the moderate thinning sample treatments (35\% thinning). HT, the heavy thinning sample treatments (50\% thinning). MBN, microbe biomass nitrogen; STN, soil total nitrogen; SOC, soil organic carbon. Each bar represents an average value across three replicate samples ( $\mathrm{n}$ $=15)$, i.e. three plots repeats $\times$ five soil depths. Error bars represent standard errors around the three plot repeats. Different lowercase letters demarcate a significant difference among different density adjustments within the same sampling season $(p<0.05)$.
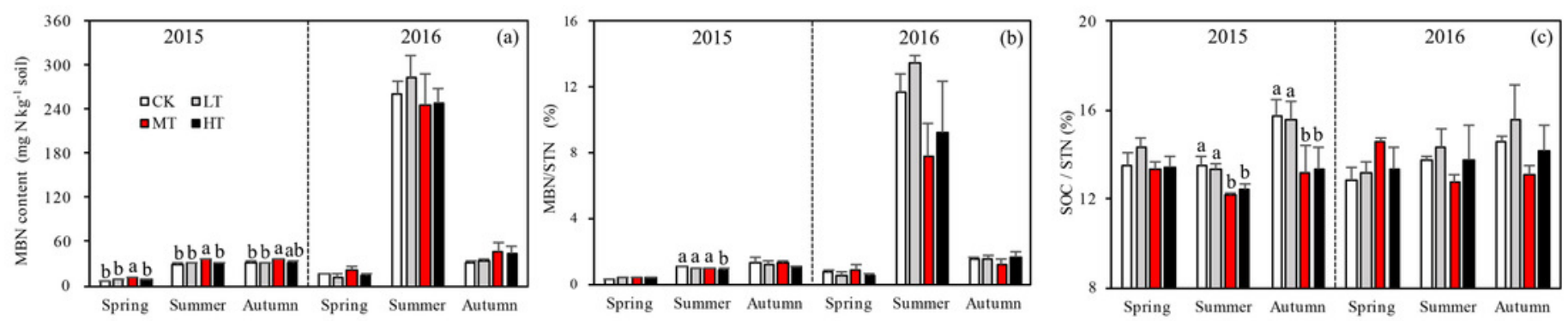


\section{Figure 5}

Pearson relationship of different soil properties across thinning treatments, seasons and soil depths.

$\mathrm{n}=360$, i.e. four density treatments $*$ three seasons $*$ three repeats $*$ five soil depths $*$ two years. $* p<0.1 ; * p<0.05 ; * * * p<0.01$.

*Note: Auto Gamma Correction was used for the image. This only affects the reviewing manuscript. See original source image if needed for review. 


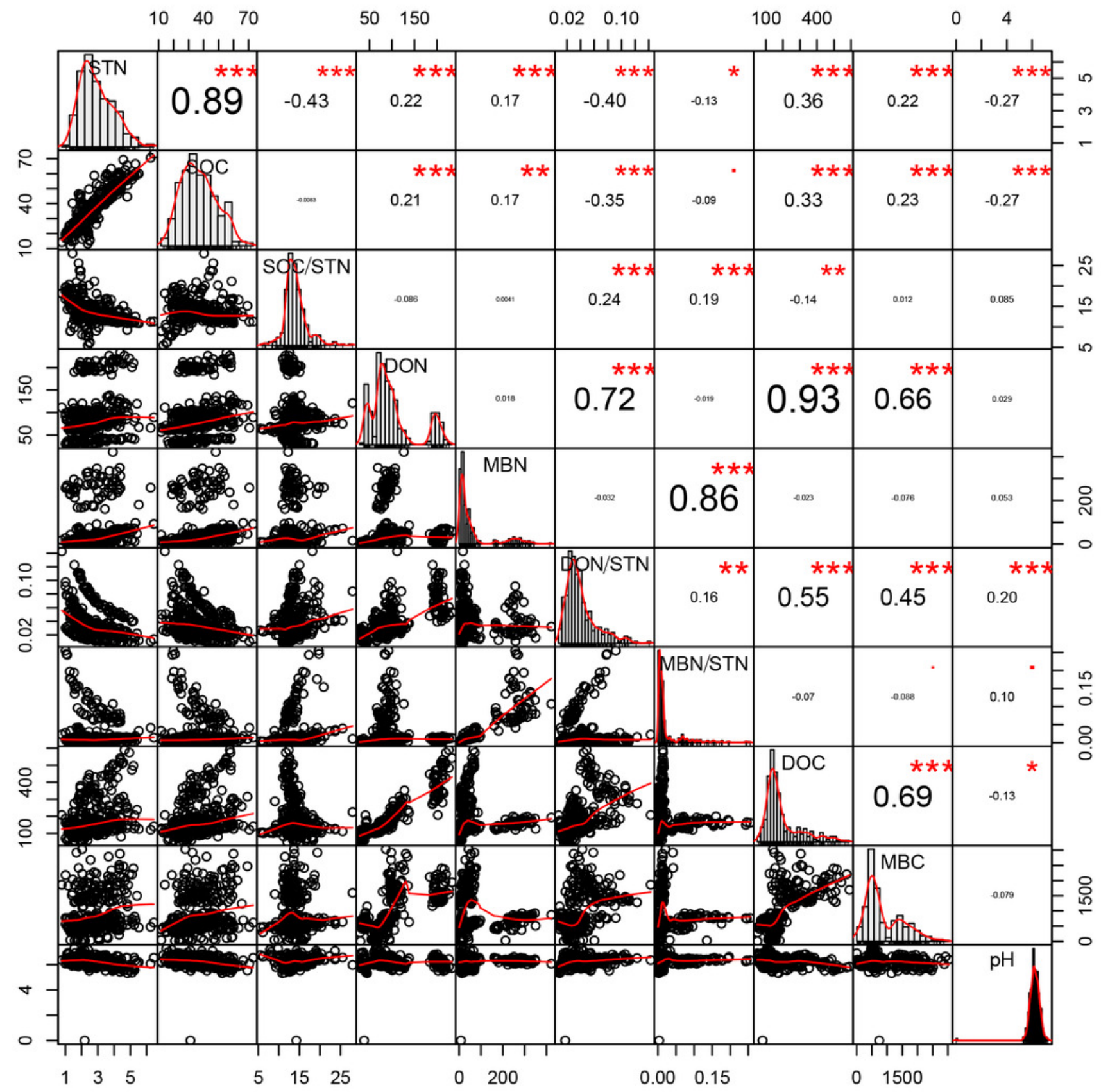




\section{Table $\mathbf{1}$ (on next page)}

Average characteristic measurements of experimental stands for density adjustment treatments in a 35-year-old Larix principis-rupprechtii plantation.

Standard errors of the mean are presented within parenthesis. Treatments: CK: no thinning control, LT: low thinning, MT: moderate thinning, HT: heavy thinning. Density adjustments and characteristics were measured in July 2012. Total phosphorus, bulk density, mechanical composition and bulk density of soil was measured in July 2015 (means $\pm S D, n=3$ ) 


\begin{tabular}{|c|c|c|c|c|c|c|c|c|c|c|}
\hline \multirow[t]{3}{*}{ Treatment } & \multirow{3}{*}{$\begin{array}{l}\text { Stems } \\
\left(\mathrm{ha}^{-1}\right)\end{array}$} & \multirow{3}{*}{$\begin{array}{l}\text { Thinning } \\
(\%)\end{array}$} & \multirow{3}{*}{$\begin{array}{l}\text { Slope } \\
\text { Gradient }\left(^{\circ}\right)\end{array}$} & \multirow{3}{*}{$\begin{array}{l}\text { Mean } \\
\text { Height }(\mathrm{m})\end{array}$} & \multirow{3}{*}{$\begin{array}{l}\text { Mean } \\
\mathrm{DBH}(\mathrm{cm})\end{array}$} & \multirow{3}{*}{$\begin{array}{l}\text { Total soil phosphorus } \\
\left(\mathrm{g} \mathrm{kg}^{-1}\right)\end{array}$} & \multirow{3}{*}{$\begin{array}{l}\text { Soil bulk } \\
\text { density } \\
\mathrm{g} \mathrm{cm}^{-3}\end{array}$} & \multicolumn{3}{|c|}{ Mechanical composition (\%) } \\
\hline & & & & & & & & & $0.002 \sim 0.05 \mathrm{~m}$ & \\
\hline & & & & & & & & $<0.002 \mathrm{~mm}$ & $\mathrm{~m}$ & $0.05 \sim 2.00 \mathrm{~mm}$ \\
\hline CK & 2173 & 0 & 25 & 14.5 & 13.3 & 0.50 & 0.91 & 20.83 & 30.40 & 48.77 \\
\hline \multirow[t]{2}{*}{ LT } & 1834 & 15 & 25 & 19.3 & 14.9 & 0.51 & 0.87 & 22.07 & 29.90 & 48.03 \\
\hline & $( \pm 12)$ & & $( \pm 3.6)$ & $( \pm 1.21)$ & $( \pm 1.29)$ & $( \pm 0.032)$ & $( \pm 0.070)$ & $( \pm 4.263)$ & $( \pm 0.589)$ & $( \pm 4.246)$ \\
\hline \multirow[t]{2}{*}{ MT } & 1418 & 30 & 23 & 16.6 & 16.3 & 0.60 & 0.95 & 18.27 & 31.93 & 49.80 \\
\hline & $( \pm 7)$ & & $( \pm 0.5)$ & $( \pm 0.21)$ & $( \pm 0.02)$ & $( \pm 0.071)$ & $( \pm 0.024)$ & $( \pm 2.117)$ & $( \pm 2.738)$ & $( \pm 1.768)$ \\
\hline \multirow[t]{2}{*}{ HT } & 1089 & 50 & 24 & 16.9 & 17 & 0.57 & 0.86 & 17.43 & 33.60 & 48.97 \\
\hline & $( \pm 3)$ & & $( \pm 2.0)$ & $( \pm 0.31)$ & $( \pm 0.65)$ & $( \pm 0.034)$ & $( \pm 0.010)$ & $( \pm 1.156)$ & $( \pm 2.570)$ & $( \pm 3.703)$ \\
\hline
\end{tabular}




\section{Table 2 (on next page)}

The environmental factors of $L$. principis-rupprechtii plantation with different thinning treatments.

Soil respiration: carbon flux of soil respiration; PPFD total over: photosynthetic photon flux density over the forest, PPFD total under: photosynthetic photon flux density under the forest. The Soil respiration, soil temperature, soil moisture was measured in the vegetation growing seasons and the values were the means of 7 months from April to October. PPFD was measured in the summer seasons, July each year. Different superscripts indicate significant difference at $p<0.05$ in thinning treatments, $n=3$. 


\begin{tabular}{llllll}
\hline Environmental factors & Year & \multicolumn{1}{c}{ CK } & \multicolumn{1}{c}{ LT } & \multicolumn{1}{c}{ MT } & HT \\
\hline Soil respiration $\left(\mathrm{g} \mathrm{C} \mathrm{m}^{-2}\right)$ & 2015 & $297.6 \pm 22.1 \mathrm{a}$ & $280.43 \pm 31.97 \mathrm{a}$ & $391.1 \pm 40.6 \mathrm{a}$ & $356.7 \pm 33.6 \mathrm{a}$ \\
& 2016 & $421.6 \pm 47.3 \mathrm{a}$ & $391.08 \pm 70.42 \mathrm{a}$ & $507.5 \pm 55.4 \mathrm{a}$ & $438.8 \pm 45.3 \mathrm{a}$ \\
& 2015 & $4.6 \pm 0.5 \mathrm{c}$ & $5.9 \pm 0.47 \mathrm{~b}$ & $6.5 \pm 0.5 \mathrm{~b}$ & $9.7 \pm 0.5 \mathrm{a}$ \\
PPFD total under $\left(\mathrm{MJ} \cdot \mathrm{m}^{-2} \cdot \mathrm{d}^{-1}\right)$ & 2016 & $4.8 \pm 0.3 \mathrm{c}$ & $5.86 \pm 0.21 \mathrm{~b}$ & $6.4 \pm 1.0 \mathrm{~b}$ & $8.1 \pm 0.4 \mathrm{a}$ \\
& 2015 & $27.9 \pm 1.2$ & $28.3 \pm 1.23$ & $28.4 \pm 0.3$ & $28.5 \pm 0.6$ \\
PPFD total over $\left(\mathrm{MJ} \cdot \mathrm{m}^{-2} \cdot \mathrm{d}^{-1}\right)$ & 2016 & $28.87 \pm 1.07 \mathrm{a}$ & $29.25 \pm 0.14 \mathrm{a}$ & $29.5 \pm 1.1 \mathrm{a}$ & $30.4 \pm 1.2 \mathrm{a}$ \\
& 2015 & $6.1 \pm 0.1 \mathrm{~b}$ & $6.3 \pm 0.3 \mathrm{~b}$ & $7.0 \pm 0.2 \mathrm{a}$ & $6.5 \pm 0.2 \mathrm{ab}$ \\
Soil temperature $\left({ }^{\circ} \mathrm{C}\right)$ & 2016 & $7.7 \pm 0.4 \mathrm{a}$ & $7.7 \pm 1.2 \mathrm{a}$ & $8.5 \pm 0.8 \mathrm{a}$ & $7.8 \pm 0.6 \mathrm{a}$ \\
& 2015 & $22.1 \pm 0.8 \mathrm{~b}$ & $24.2 \pm 3.3 \mathrm{ab}$ & $27.1 \pm 1.9 \mathrm{ab}$ & $28.7 \pm 2.1 \mathrm{a}$ \\
Soil moisture $(\%)$ & 2016 & $22.7 \pm 1.4 \mathrm{~b}$ & $24.1 \pm 2.9 \mathrm{ab}$ & $25.0 \pm 2.2 \mathrm{ab}$ & $28.2 \pm 1.2 \mathrm{a}$ \\
\hline
\end{tabular}




\section{Table 3(on next page)}

Biomass $\left(t \mathrm{ha}^{-1}\right)$ of the $L$. principis-rupprechtii plantation with different thinning treatments.

Values mean $\pm S D$; different superscripts indicate a significant difference at $p<0.05$ in thinning treatments; Biomass data was collected in July 2014 and the total biomass is the sum of the three layers (tree, understory and little layer). 


\begin{tabular}{|c|c|c|c|c|c|}
\hline \multirow{2}{*}{ Components } & \multicolumn{5}{|l|}{ Treatments } \\
\hline & $\mathrm{CK}$ & LT & MT & HT & Mean \\
\hline Tree layer & $189.58 \pm 2.06 \mathrm{a}$ & $159.17 \pm 7.59 \mathrm{~b}$ & $144.98 \pm 5.58 \mathrm{bc}$ & $135.55 \pm 3.44 \mathrm{c}$ & $157.32 \pm 23.60$ \\
\hline Understory layer & $2.24 \pm 0.25 \mathrm{a}$ & $2.83 \pm 0.42 \mathrm{a}$ & $5.56 \pm 1.14 \mathrm{a}$ & $6.95 \pm 1.57 \mathrm{a}$ & $4.40 \pm 2.23$ \\
\hline Litter layer & $61.88 \pm 10.53 \mathrm{a}$ & $57.71 \pm 14.55 \mathrm{a}$ & $62.35 \pm 14.49 \mathrm{a}$ & $60.84 \pm 19.38 \mathrm{a}$ & $60.70 \pm 2.09$ \\
\hline Total & $253.70 \pm 8.72 \mathrm{a}$ & $219.70 \pm 22.48 \mathrm{ab}$ & $212.90 \pm 17.33 \mathrm{ab}$ & $203.33 \pm 18.67 \mathrm{~b}$ & $222.41 \pm 21.92$ \\
\hline
\end{tabular}




\section{Table 4 (on next page)}

Three-way ANOVA analysis of soilproperties to year, season and density (or thinning treatment).

Df (degree of freedom), STN (soil total nitrogen), SOC (soil organic carbon), MBN (microbial biomass nitrogen), DON (dissolved organic nitrogen), MBC (microbial biomass carbon), DOC (dissolved organic carbon). For each property, data was pooled from 360 independent samples, e.g. Two sampling years * three seasons * four thinning treatments * five soil depths * three repetitions. 


\begin{tabular}{|c|c|c|c|c|c|c|c|c|c|c|c|}
\hline \multirow[t]{2}{*}{ Factors } & \multirow[t]{2}{*}{ Df } & & SOC & $\begin{array}{l}\text { SOC } \\
/ \text { STN } \\
\end{array}$ & DON & MBN & DOC & $\mathrm{MBC}$ & $\mathrm{pH}$ & \multirow{2}{*}{$\begin{array}{c}\text { MBNSTN } \\
\mathrm{p}\end{array}$} & \multirow{2}{*}{$\frac{\mathrm{DON} / \mathrm{STN}}{\mathrm{p}}$} \\
\hline & & $\mathrm{p}$ & $\mathrm{p}$ & $\mathrm{p}$ & $\mathrm{p}$ & $\mathrm{p}$ & $\mathrm{p}$ & $\mathrm{p}$ & $\mathrm{p}$ & & \\
\hline Treatment & 3 & $<0.001$ & $<0.001$ & 0.001 & 0.862 & 0.805 & 0.318 & 0.014 & 0.315 & 0.022 & $<0.001$ \\
\hline Season & 2 & $<0.001$ & 0.004 & $<0.001$ & $<0.001$ & $<0.001$ & $<0.001$ & $<0.001$ & $<0.001$ & $<0.001$ & $<0.001$ \\
\hline Year & 1 & 0.001 & $<0.001$ & 0.424 & $<0.001$ & $<0.001$ & $<0.001$ & $<0.001$ & $<0.001$ & $<0.001$ & $<0.001$ \\
\hline Treatment $*$ Season & 6 & 0.288 & 0.243 & 0.012 & 0.37 & 0.368 & 0.003 & 0.005 & 0.352 & 0.007 & 0.007 \\
\hline Treatment * Year & 3 & 0.496 & 0.943 & 0.169 & 0.795 & 0.774 & 0.478 & $<0.001$ & 0.745 & 0.03 & 0.375 \\
\hline Season * Year & 2 & 0.827 & 0.011 & 0.134 & $<0.001$ & $<0.001$ & $<0.001$ & $<0.001$ & 0.002 & $<0.001$ & $<0.001$ \\
\hline Treatment $*$ Season * Year & 6 & 0.039 & 0.05 & 0.596 & 0.017 & 0.331 & $<0.001$ & 0.02 & 0.594 & 0.009 & 0.302 \\
\hline
\end{tabular}

